\title{
Protein $\mathrm{Z}$ gene polymorphisms (intron F $79 \mathrm{G}>\mathrm{A} ;-\mid 3 \mathrm{~A}>\mathrm{G}$ ) are not associated with acute coronary syndromes
}

\author{
Francesca Cesari', Cinzia Fatini', Elena Sticchi', Sandra Fedi', Rosanna Abbate', Gian Franco Gensini ${ }^{1,2}$, \\ Francesco Sofi ${ }^{1}$
}

'Department of Medical and Surgical Critical Care, Thrombosis Centre, University of Florence, Italy; Center for the Study at Molecular and Clinical Level of Chronic, Degenerative and Neoplastic Diseases to Develop Novel Therapies, University of Florence, Italy; ${ }^{2}$ Centro S. Maria agli Ulivi, Fondazione Don Carlo Gnocchi, Onlus IRCCS, Impruneta, Florence, Italy

\section{Dear Sir,}

Protein Z, a vitamin K-dependent plasma glycoprotein, has been reported to exert an important role in inhibiting coagulation by acting as cofactor for the inactivation of activated factor $\mathrm{X}$ through the formation of a complex with a protein Z-dependent protease inhibitor (1). During the last years, low protein Z levels have been found to be related to cerebral as well as coronary atherosclerotic diseases (2, 3). Actually, in 2004 Santacroce et al. demonstrated, in a healthy population, a significant influence of the protein $\mathrm{Z}$ gene $79 \mathrm{G}>\mathrm{A}$ polymorphism on protein $\mathrm{Z}$ plasma levels (4). In addition, more recently, two papers reported a possible relationship between protein $Z$ gene polymorphisms and the occurrence of ischemic stroke $(5,6)$.

In order to evaluate the relationship between protein $\mathrm{Z}$ gene polymorphisms ( $79 \mathrm{G}>\mathrm{A} ;-13 \mathrm{~A}>\mathrm{G}$ ) protein $\mathrm{Z}$ levels and acute coronary syndromes (ACS), we investigated 244 unrelated patients (188 male; 56 female; median age: 64 years) and 352 (271 males; 81 females; median age: 63 years) age- and sex-comparable healthy subjects. Patients were consecutively admitted for percutaneous coronary intervention at the Catheterization Laboratory of the Department of Heart and Vessels of the University of Florence. ACS was diagnosed according to criteria established by the American College of Cardiology and the European Society of Cardiology (7). The coronary angiography was performed by the Judkins' method, and coronary vessels with at least $75 \%$ stenosis were defined as diseased. Acute myocardial infarction occurred in $120(49.2 \%)$ and unstable angina in 124 $(50.8 \%)$ patients. Monovessel disease was present in 185 (75.8\%) patients, whereas bivessel and trivessel disease was present in $51(20.9 \%)$ and 8 (3.3) patients, respectively.

The control group consisted of 352 unrelated subjects recruited from the staff of the University of Florence and from partners or friends of patients. All subjects gave informed consent; the study complies with the Declaration of Helsinki and was approved by the local ethic committee. Protein Z levels were measured by using a commercial assay (Asserachrom Protein Z;

Correspondence to:

Francesca Cesari, BS

Department of Medical and Surgical Critical Care

Thrombosis Centre, University of Florence

Azienda Ospedaliero-Universitaria Careggi

Viale Morgagni 85, 50I34 Florence, Italy

Tel.: +39-055-7949420, Fax: +39-055-79494I8

E-mail: francesca.cesari@gmail.com

Received January 17, 2006

Accepted after revision May 14, 2006

Prepublished online June I4, 2006 doi: I0.1 I60/TH06-0|-003।

Thromb Haemost 2006; 96: 98-9
Diagnostica Stago, Asnieres, France). Protein Z gene polymorphisms were analysed as previously reported (5). Statistical analyses were performed by using the SPSS (Statistical Package for Social Sciences, Chicago, IL, USA) software for Windows (Version 12.0). Mann-Whitney test for unpaired data was used for comparisons between single groups, and the Kruskal-Wallis test was used for comparisons among different groups. The $\mathrm{Chi}^{2}$-test was used for testing Hardy-Weinberg equilibrium of both polymorphisms. Univariate logistic regression analysis was performed with ACS as independent variable to test for an association between protein $\mathrm{Z}$ gene polymorphisms and ACS. Multivariate model with adjustment for possible confounders was not performed due to the not significant association found in the univariate model. A p-value $<0.05$ was considered to indicate statistical significance. Confidence intervals (CI) were calculated at the $95 \%$ level.

Protein Z plasma levels were found to be significantly lower in patients than in healthy controls $(1431.6 \pm 758.2$ vs. $1738.9 \pm$ $641.6 \mathrm{ng} / \mathrm{ml} ; \mathrm{p}<0.0001)$. Both polymorphisms investigated were in Hardy-Weinberg equilibrium. Neither genotype distribution $(\mathrm{p}=0.3$, and $\mathrm{p}=0.6$ for $-13 \mathrm{~A}>\mathrm{G}$ and $79 \mathrm{G}>\mathrm{A}$ polymorphisms, respectively) nor allele frequency for both polymorphisms was significantly different between patients and controls [allele frequency: (-13G: 0.06 vs. $0.08 ; p=0.3),(79 A: 0.20$ vs. $0.18 ; p=0.5$ ) for patients and controls, respectively]. Protein $\mathrm{Z}$ levels were found to be significantly lower according to the different genotypes for both polymorphisms, as concerned the presence of the variant rare alleles (Table 1). As regarding $79 \mathrm{G}>\mathrm{A}$ polymorphism, the influence of the 79A allele on circulating levels of the protein is evident within the whole population as well as among patients and controls taken separately. On the contrary, the -13 $A>G$ polymorphism significantly influenced protein $Z$ levels in the whole population and in control subjects but not among patients. Notably, protein Z levels are reported to be significantly lower in patients compared to controls even within the different genotypes of the $79 \mathrm{G}>\mathrm{A}$ polymorphism. Logistic regression analysis found no association between rare alleles and ACS $(-13 \mathrm{AG}+\mathrm{GG}$ : OR $0.8,95 \%$ CI $0.5-1.2, \mathrm{p}=0.3 ; 79 \mathrm{GA}+\mathrm{AA}:$ OR $1.2,95 \%$ CI $0.8-1.6, \mathrm{p}=0.3)$. Similarly, the contemporary presence of the two variants was not significantly associated to the disease $(-13 \mathrm{AG}+\mathrm{GG} / 79 \mathrm{GA}+\mathrm{AA}$ : OR $0.9,95 \%$ CI $0.5-1.7$, $\mathrm{p}=0.8$ ).

We found that rare alleles of polymorphisms encoding the protein $\mathrm{Z}$ gene (intron $\mathrm{F} 79 \mathrm{G}>\mathrm{A}$ and $-13 \mathrm{~A}>\mathrm{G}$ ) are not significantly associated with the occurrence of ACS. This is at variance with Lichy et al. (5) and with Staton et al. (6) who reported a significant protective effect of the 79A allele of the intron F $79 \mathrm{G}>\mathrm{A}$ 
Table I: Protein Z levels according to genotype distribution for protein Z gene polymorphisms.

\begin{tabular}{|c|c|c|c|c|c|c|c|c|}
\hline & \multicolumn{3}{|c|}{$-13 A>G$} & & \multicolumn{3}{|c|}{ Intron F 79 G>A } & \multirow[b]{2}{*}{$\mathrm{p}$} \\
\hline & $-13 A A$ & $-13 A G$ & $-13 G G$ & $\mathrm{p}$ & 79GG & 79GA & 79AA & \\
\hline $\begin{array}{l}\text { Total } \\
(n=596)\end{array}$ & $\begin{array}{l}1758.8 \pm 739.6 \\
(n=5 \mid 2)\end{array}$ & $\begin{array}{l}1567.5 \pm 655.7 \\
(\mathrm{n}=84)\end{array}$ & - & 0.01 & $\begin{array}{l}1722.1 \pm 663.8 \\
(n=389)\end{array}$ & $\begin{array}{l}\mid 430.8 \pm 726.4 \\
(n=19 \mid)\end{array}$ & $\begin{array}{l}1138.7 \pm 893.8 \\
(n=16)\end{array}$ & $<0.0001$ \\
\hline $\begin{array}{l}\text { Patients } \\
(n=244)\end{array}$ & $\begin{array}{l}1736.4 \pm 844.1 \\
(n=214)\end{array}$ & $\begin{array}{l}1597 \pm 850.6 \\
(n=30)\end{array}$ & - & 0.3 & $\begin{array}{l}1593.8 \pm 738.2 \\
(n=154)\end{array}$ & $\begin{array}{l}1193 \pm 714.8 \\
(n=84)\end{array}$ & $\begin{array}{l}611 \pm 449.9 \\
(n=6)\end{array}$ & $<0.0001$ \\
\hline $\begin{array}{l}\text { Controls } \\
(n=352)\end{array}$ & $\begin{array}{l}1772.9 \pm 655.4^{\wedge} \\
(n=298)\end{array}$ & $\begin{array}{l}|551 .| \pm 526.1 \\
(n=54)\end{array}$ & - & 0.01 & $\begin{array}{l}1806.2 \pm 596.9^{*} \\
(n=235)\end{array}$ & $\begin{array}{l}1617.4 \pm 682.5^{\wedge} \\
(n=107)\end{array}$ & $\begin{array}{l}1455.4 \pm 959.8^{\circ} \\
(n=10)\end{array}$ & 0.02 \\
\hline
\end{tabular}

Data are expressed as mean $\pm S D .{ }^{*} p=0.03$ vs. $79 \mathrm{GG}$ patients. ${ }^{\wedge} p<0.0001$ vs. $79 \mathrm{GA}$ patients. ${ }^{\circ} p<0.000 \mathrm{I}$ v. $79 \mathrm{AA}$ patients.

polymorphism on the occurrence of ischaemic stroke. The difference might be explained by the different genetic background, selection of patients and controls as well by the higher number of controls in our study, especially if we take into consideration that the analysis performed by Staton et al. (6) was conducted by pooling data from the study of Lichy et al. (5). Actually, the control group represents a key factor for genetic studies concerning polymorphisms, and it is likely that the association shown by previous studies for the variant rare alleles of these two polymorphisms disappears as the number of controls increases.

In addition, we found a significant influence of protein $\mathrm{Z}$ gene polymorphisms on protein $\mathrm{Z}$ plasma levels in a considerable number of subjects, including ACS patients and healthy controls. This finding is in keeping with previous studies which evaluated these two polymorphisms in relation to ischaemic stroke and among healthy controls (4-6). Indeed, both protein Z gene rare alleles were found to be associated with lower levels of the protein in the whole population and in control subjects, whereas, among patients, only the 79A variant of the intron $\mathrm{F} 79$ $\mathrm{G}>\mathrm{A}$ polymorphism was significantly associated with lower levels of protein $\mathrm{Z}$. This could be explained by the low allele frequency demonstrated by the rare allele of the $-13 \mathrm{~A}>\mathrm{G}$ polymorphism, which therefore may require a higher number of patients to obtain a statistical significance. The reasons why protein $Z$ gene polymorphisms influence protein $\mathrm{Z}$ plasma levels but are not significantly associated with the occurrence of disease are not completely known and need to be further clarified. In conclusion, the present study shows that protein $\mathrm{Z}$ gene polymorphisms are not per se associated with the occurrence of ACS, while it confirms the previous findings of an influence of protein $Z$ gene on protein $Z$ plasma levels, extending the results to patients with ACS.

\section{References}

1. Broze GJ. Protein Z-dependent regulation of coagulation. Thromb Haemost 2001; 86: 8-13.

2. Vasse M, Guegan-Massardier E, Borg JY, et al. Frequency of protein $\mathrm{Z}$ deficiency in patients with ischaemic stroke. Lancet 2001; 357: 933-4.

3. Sofi F, Cesari F, Vigiani S, et al. Protein Z plasma levels in different phases of activity of coronary atherosclerosis. J Thromb Haemost 2005; 3: 2254-8.

4. Santacroce R, Cappucci F, Di Perna P, et al. Protein $\mathrm{Z}$ gene polymorphisms are associated with pro- tein Z plasma levels. J Thromb Haemost 2004; 2: 1197-9.

5. Lichy C, Kropp S, Dong-Si T et al. A common polymorphism of the protein $\mathrm{Z}$ gene is associated with protein $Z$ plasma levels and with risk of cerebral ischemia in the young. Stroke 2004; 35: 40-5.

6. Staton J, Sayer M, Hankey GJ, et al. Protein Z gene polymorphisms, protein $\mathrm{Z}$ concentrations, and ischemic stroke. Stroke 2005; 36: 1123-7.
7. Braunwald E, Antman EM, Beasley JW, et al. ACC/ AHA Guideline Update for the Management of Patients with Unstable Angina and Non-ST-segment Elevation of Myocardial Infarction-summary article: a report of the American College of Cardiology/American Heart Association task force on practice guidelines (Committee on the Management of Patients with Unstable Angina). J Am Coll Cardiol 2002; 40: 1366-74. 